\title{
How do Museums Foster Loyalty in Tech-Savvy Visitors? The Role of Social Media and Digital Experience
}

\begin{abstract}
The recent debate about the digitalization of museums and new technologies has become increasingly important among tourism scholars. Digital innovation and virtual environments, such as social media platforms, might significantly foster the competitive advantage of museums and their ability to attract new visitors. Particularly in times of crisis, prospective tourists appreciate the addition of a "digital flavor" to exhibitions and art galleries. Improved experiences, increased loyalty, and overall higher satisfaction result from the introduction of Internet Communication Technologies (ICTs) in museums. Building on experiential marketing and the extended technology acceptance model (TAM2), a conceptual model has been created to better explore the underlying mechanisms between tourists' digital propensity - their positive attitudes towards digital innovation and new technologies - and their degree of economic support to museums. The model was empirically validated through confirmatory factor analysis (CFA) and tested using covariance-based structural equation modeling (CB-SEM) on a sample collected in 2020 consisting of 201 Italian museum visitors. Results showed that loyalty and identification derived from digital experiences and social media activities cause techsavvy visitors to be more willing to economically support digital museums.
\end{abstract}

\section{Keywords:}

Digital museum; Loyalty; Identification with museum; Cultural heritage management; Museum marketing; Social media marketing. 


\section{Introduction}

Museums are a fundamental contributor to the fabric of society (Ayala, Cuenca-Amigo, \& Cuenca, 2019). Thanks to museums, ancient and modern artworks, cultural heritage goods, and natural beauties are preserved and admired by future generations. The increase in museum visitors - COVID-19 aside - peaked in 2019, with several museums surpassing the 5 million visitors mark (the Louvre was visited by 9.7 million visitors and the Vatican Museum by 6.3; Statista, 2019). Millennials - the generation born from the late 80 s to the first years of the new millennium (Zollo, Filieri, Rialti, $\&$ Yoon, 2020) - have emerged as the predominant cohort of visitors (Statista, 2018). Museums thus represent a fundamental means through which a continuum between the past, present, and the future of a specific territory is generated (McLean, 1994), however they are economically fragile (Fissi, Gori, \& Contri, 2018). Museums are extremely dependent on governmental funds and rely on revenue from visitors' access fees. Therefore, in times of economic downturn and travel blockade, as a result of the COVID-19 pandemic (Samaroudi, Echavarria, \& Perry, 2020), these organizations particularly the older ones - need to learn new and innovative ways to remain economically and financially sustainable. Tourist policy makers are vital in effectively exploiting social media communication to preserve image and reputation, especially in times of crisis (Yu, Li, Yu, He, \& Zhou, 2020). Digitalization can dramatically affect museums' revenue generation. ICT influences two main elements: how museums arrange their collections and how visitors receive information (Pallud \& Straub, 2014). ICT can improve the way curators arrange rooms and parts of an exhibition can be digitalize (Romolini, Fissi, \& Gori, 2020). Using technologies such as smartphone applications, visitors can receive more information during and after their visit (Fissi, 
Gori, Romolini, \& Contri, 2019). ICT can also make museums 'always on and always with you' (Cohen, 2016).

Museum experience is related to visitors' perceived ease of information access (Karaman, Bagdanov, Landucci, D’Amico, Ferracani, Pezzatini, \& Del Bimbo 2016; Rialti, Zollo, Boccardi, \& Marzi, 2016). The more information is customized and understandable, the better the visitors' experience will be. ICT can cultivate loyalty towards the museum and stimulate intention to revisit (Cillo, Rialti, Del Giudice, \& Usai, 2019). Museums' online presence in virtual environments, such as social media platforms and Social Media Marketing initiatives/activities (SMMs), which represent strategic digital touchpoints during both pre- and post-purchase experiences (Kim \& Ko, 2012), can also aid this. Posting photos and comments on social networking sites like Instagram and Telegram has a positive effect on the tourism experience in terms of branding and intention to revisit (Ebrahimi, Hajmohammadi,\& Khajeheian, 2020). Despite increasing academic interest, some research gaps remain concerning the digitalization of museums and the introduction of new technologies. First, most studies assume a qualitative approach - i.e., case studies based on a specific museum (Bonacini, 2016). Next, the way ICT and new technologies influence visitors' behavioral intentions regarding supporting museum development should be better explored (Cerquetti, 2016). Furthermore, existing literature tends to focus on engineering (Karaman et al., 2016), thus examining technological characteristics and effective infrastructure development. This research seeks to fill these gaps, exploring how visitors' digital propensity indicative of their attitudes towards new technology - may foster the development of a positive experience, assessing the outcomes museums might derive from this.

Specifically, we focus on visitors' intent to support the economic activities of museums in difficult times, such as those currently faced. To do so, a conceptual model has been 
developed, building on experiential marketing (Pine \& Gilmore, 1998; Brakus, Schmitt, \& Zarantonello 2009) and the extended technology acceptance model (TAM2;

Venkatesh \& Davis, 2000), investigating the role of museums' SMMs and digital experiences in fostering visitors' identification with and loyalty to the museum which, in turn, fosters economic support. The model was then empirically tested in 2020 on visitors of Tuscan museums (Italy): one of the most important regions not only in Italy but also in Europe in terms of art, museums, and cultural heritage (ISTAT, 2020). Following the introduction, this paper is structured as follows. The next section concerns the impact of ICT on experience development and visitor loyalty, developing our main hypotheses and presenting the conceptual model. The third and fourth sections outline the methodology and the results of the empirical analysis. Finally, the fifth section presents several theoretical and managerial implications for both researchers and practitioners interested in digitalization strategies.

\section{Theoretical background and hypotheses development}

Museums and new challenges: how an audience-centric perspective improves visitors'

\section{experiences?}

A museum's role in addressing the challenges of society is, nowadays, increasing at an overwhelming pace (Cerquetti, 2016). Social changes have amplified and emancipated cultural diversities and, consistently, new consumers with different cultural needs have emerged. Henceforth, museums should promote artistic heritage by emphasizing social dynamism, active participation, and multiculturalism (Ayala et al., 2019). Until today, museums have traditionally highlighted the importance of their exhibitions using an object-based approach. Museums' competitiveness was thus dependent on the quantity, variety, and value of the cultural artifacts forming their exhibitions (McLean, 1994; 
Kawashima, 1998). In recent times, populated by eager and more tech-savvy consumers, a paradigmatic shift has occurred. The exhibition itself is no more adept at satisfying requests and expectations of visitors. These guests wish to be involved in museum activities and feel part of the museums' history, heritage, and development (Easson \& Leask, 2019), thus co-creating value with the museum through engagement with it and the other visitors (Payne, Storbacka, \& Frow, 2008).

The centrality of the ensemble of visitors, known as museum audience (Dirsehan \& Yalçin, 2011; Pesce, Neirotti, \& Paolucci, 2019), is emerging as a dominant archetype in museum management and marketing literature. A nascent stream of research is considering how museum management should follow the audience-centric paradigm (Taheri, Jafari, \& O'Gorman, 2014). Scholars have observed how managers and marketers of museums and cultural organizations alike (i.e., art galleries, open-air exhibitions, archeological excavations, industrial heritage sites, and theme parks) must strategically place the audience at the forefront of their activities and initiatives. The audience, therefore, becomes the core focus of the museum's activities, with exhibitions arranged around visitors' requests, preferences, and expectations. According to Kelly (2004, pp.48-49), "the challenges museums face has resulted in a conceptual shift for museums, from being primarily curator driven to becoming market-responsive, focusing on the needs of audiences" (see Trunfio, Campana, \& Magnelli, 2020). From the perspective of curators and museum managers, developing an audience is a new strategic lever: museums should develop marketing strategies to attract and retain visitors in order to better compete with different cultural organizations (Dirsehan \& Yalçin, 2011). Audience research is keenly focused on visitors' experiences. To attract new visitors, museums should create experiences that differentiate them from their competitors, thus enhancing satisfaction through the perceived customization of the 
exhibition (Dominguez-Quintero, González-Rodríguez, \& Paddison ,2020). Museum visitors then behave as consumers who pursue satisfaction as a consequence of museum experiences (Harrison \& Shaw, 2004). This is coherent with consumer behavior, according to the experience economy model (Pine \& Gilmore, 1998). Visitors, like consumers, shift their preferences towards providers capable of supplying them with a differentiated approach with unique experiential offerings (Rialti, Caliandro, Zollo, \& Ciappei, 2018). The obtained value is increasingly related to intangible and memorable feelings, differentiating one provider from another (Zollo et al., 2020). Experiences engage consumers and cultivate loyalty.

In the digital era, ICT - including technologies transmitting information through the use of digital media (Sashi, 2012) - is a tool museums can use to enhance visitors' participation, developing meaningful experiences (Rialti et al., 2016). Multimedia elements could combine with the real experiences of visitors, thus presenting unusual possibilities for companies (Trunfio et al., 2020). ICT could foster the development of gratification, entertainment, and education. The more customized information a consumer can get, the better the experience (Neuhofer, Buhalis, \& Ladkin, 2014). ICT is thus becoming a constituent of the experience itself. Museums should therefore work on two strategic marketing levers: 1) diversification from other cultural organizations and 2) the attraction of new audiences. Following this approach, the micro-mechanisms underpinning the relationship between ICT and museum experiences need to be carefully considered.

\section{ICT and Museum Digital Experiences: The Rise of the Tech-Savvy Cultural Consumer}

Current debates on the importance of museum visitors' experiences are still fragmented (Dominguez-Quintero et al., 2020). On the one hand, a more traditional stream of 
literature considers museums as necessarily elitist. Accordingly, experience should mostly derive from existing competences and visitors' previous abilities to appreciate artwork (David, 1999; Hooper-Grenhill, 2000). On the other hand, massified society theorists discuss how museums should be accessible for all. The role of curators and managers is thus to provide visitors with the tools to gather knowledge, ensuring an immersive visit (O’Connor, Nelson, Pradhananga, \& Earnest, 2020).

According to recent research in this area, ICT plays a huge role in this regard. To enhance audience development, a growing number of museums offer visitors the opportunity to experience exhibitions live using technologies (Kesner, 2006). ICT is interactive, fostering a dialogic communication in real-time with consumers. ICT can be controlled and managed directly by visitors, allowing them to skip content they do not appreciate and perfectly customize their visit (Belanche, Flavián, \& Pérez-Rueda, 2017). ICT is therefore increasingly used to enhance tourists' experiences (Cillo et al., 2019; tom Dieck, Jung, \& tom Dieck, 2018). Museums should provide contexts in which visitors might create and live their own experience: in this way, visitors can become more actively engaged with the museum, thus co-creating its value (Payne et al., 2008). ICT strengthens audience development strategies through the creation of new interacting experiences, which develop through two dimensions: consumer connection and participation (Pine \& Gilmore, 1998). ICT contributes through interactivity and bidirectionality (Perez-Sanagustin, Parra, Verdugo, García-Galleguillos, \& Nussbaum, 2016).

Experience is derived from active or passive participation in specific activities. The development of new technologies has changed how people live and perceive experiences. Interactive ICT breaks traditional perceptions of museums motivating audiences to be more engaged (Pujol-Tost, 2011). The digitalization of museums (i.e., 
through virtual/augmented reality, videos, touchscreens, and 'smart' devices) guarantees interaction and immersion (Li, Liew, \& Su, 2012). “[Experiences] do not occur only after consumption; they occur whenever there is a direct or indirect interaction" with a stimulus (Brakus et al., 2009, p.54). Regardless of context, an individual's experience is affected by sensory stimulation through external direct or indirect factors, triggering the development of positive or negative memories. As with brand experience hypothesized by Brakus et al. (2009), the core elements of visitor experiences should be sensory, affective, behavioral, and intellectual. Building on Pine and Gilmore (1998), we consider ICT capable of triggering museum-related experiences, comparing visitors' behaviors to non-museum consumers' behaviors (see Brakus et al., 2009). ICT use is comparable to consumption: ICT initiates connections. Technological connection is environmental, linking visitors to museums (Pine \& Gilmore, 1998) through new digital experiences, such as through digitally mediated information (Rialti et al., 2016). Padilla-Meléndez and Águila-Obra (2013, p.892) stated "the introduction of multimedia information systems, based on Web and social media use, enables museums to redesign traditional products and promote new cultural experiences". According to the Extended Technology Acceptance Model (TAM2; Venkatesh \& Davis, 2000), positive effects occur through visitors' willingness to use digital technology. This eagerness - digital propensity - may be significant in influencing the overall acquired experiences (Zollo et al., 2020). Venkatesh and Davis (2000) argue that TAM2 digital propensity and experience could influence attitudes/intentions/behaviours regarding technology. Building on this, we propose:

H1a: Visitors' digital propensity positively influences digital experiences. 
In the wave of digitalization, social media can be a natural "online complement" to onsite activity (Sawyer, Griffiths, Light, Lincoln, \& Kidd, 2011). To reach new audiences - particularly younger, more tech-savvy visitors (Zollo et al., 2020) - museums should use SMM strategies (Bonacini, 2016). Social media are bi-directional online platforms, facilitating communication via video, photos, and text messages (Kaplan \& Haenlein, 2010). In museum marketing, social media could influence experiences by allow visitors to remain in touch before and after their visit. SMMs increase interaction and collaboration through information exchange (Rialti et al., 2016). Seminal studies on SMMs demonstrate that companies not using social media as a marketing strategy miss a significant opportunity to reach new customers, particularly tech-savvy ones (Kim \& Ko, 2012). Research shows that, when attitudes towards digital channels are positive, consumers will be likely to follow social media guidance (Cheng, Blankson, Wang, \& Chen, 2009). Digital propensity posits that technologies such as social media contribute to improving control, flexibility, and efficiency in daily life (Parasuraman, 2000). Hence, we propose:

H1b: Visitors' digital propensity positively influences how they perceive SMM activities of museums.

\section{Digital Experience, SMMs, and Museum Loyalty}

The ICT and SMMs activities of a museum are strategic instruments when creating digital experiences. Visitors can have direct or indirect interactions with the museum in this way. ICT can be considered distinctive in museums (Suhartanto, Brien, Primiana, Wibisono, \& Triyuni, 2019; Trunfio et al., 2020). Any form of consumption experience can be linked to notions of loyalty (Pallud \& Straub, 2014; Zarantonello \& Schmitt, 2013) as a behavioral outcome of experiential marketing. According to attitude theory 
(Bagozzi, 1992), every phenomenon produces cognitive and affective effects - i.e., memories constituting the experience - that add to consumer loyalty through satisfaction (San Martin, Collado, \& Rodriguez del Bosque, 2013). In today’s competitive context, organizations must generate followership and loyalty among visitors. The current state of the sector suggests a greater need for museums to understand variables related to guests' visits; especially their intent to revisit (tom Dieck et al., 2018).

In our study, visitors' perceived museum SMMs is the first cognitive variable that will produce loyalty as an outcome. We hypothesize that the experiential variable - visitors' digital experience - produces affective components towards the organization, i.e., loyalty. Many studies have stressed the importance of these two elements regarding museum visitor loyalty (Parasuraman \& Grewal, 2000; Petrick \& Backman, 2002). Loyalty occurs post-consumption: a pleasant experience is satisfying and leads to increased loyalty (Bigné, Mattila, \& Andreu, 2008). SMMs produce a similar effect. One essential psychological need is to feel socially connected (Gangadharbatla, 2008). Thanks to ICT and SMMs, visitors can fulfill their "desire for social interaction, [which] is stated as one of the motivations of consumers to engage in content generation activities in online environments. Perhaps the most important advantage for companies in supporting communities is increasing [...] loyalty" (Laroche, Habibi, \& Richard, 2013, p.77).

Building on this, we propose:

H2a: Digital experience positively influences visitors' loyalty to museums. H2b: Museum SMMs positively influence visitors' loyalty to museums. 
According to Pine and Gilmore (1998), experiences can have emotional, physical, spiritual, intellectual connotations. Experience can be considered the relationship between people and the world (Tung \& Ritchie, 2011). Digital technologies might enable visitors to have memorable experiences comparable to flow: absorption in a specific activity. Flow is an optimal experience, characterized by full concentration, complete control, a distortion of time, and an intrinsic enjoyment of an activity (Csikszentmihalyi, 1990). Consistent with flow components, every experience is constructed through multiple trajectories. Lived experience is a process through which people can capture identity, i.e., the tools people use to define themselves. Through experiences, individuals perceive and attribute value, senses, and meanings to their identity. Identification is strongly connected to commitment; especially affective commitment (Meyer, Allen, \& Smith, 1993). Digital experiences lead visitors to identify themselves with their actions, developing affection toward the museum. Affective commitment ties the individual to an organization and its values in a sincere and voluntary way, which develops after repetitive contact (Vandenberghe, Bentein, \& Panaccio, 2017). Identification takes place when an individual develops an idea of himself that is not dissimilar to the values and attitudes of the organization, while affection represents a strong acceptance of and empathy for organizational goals and values. As a result, affective commitment is connected to people's emotional attachment to the organization (Fu, Bolander, \& Jones., 2009). Building on research concerning the outcomes of identification, identification could also garner increased museum loyalty (Liu, Hultman, Eisingerich, \& Wei 2020).

Thus, we hypothesize:

H3a: Digital experience positively influences visitors' identification with the museum. 
H3b: Visitors' identification with the museum positively influences visitors' loyalty to the museum.

We hypothesize visitors' identification with the museum as the mediating variable of the relationship between digital experience and museum loyalty. Hence:

H4: Visitors' identification with the museum significantly mediates the relationship between digital experiences and museum loyalty.

\section{Visitors' economic support of the museum}

In the new economic crisis, museums have struggled to find the necessary funds to survive. Because of the COVID-19 pandemic, museums were in a dire situation. Visitors' economic contributions - which usually complement public funding - were almost completely irradicated. This led museum managers to implement different financial strategies to ensure their survival (Samaroudi et al., 2020). More and more museums are focusing on strategies to increase local visitors and source donations from local and foreign supporters. For instance, if foreign visitor numbers plummet, dual pricing - wherein foreign visitors pay a higher price than local visitors - could assist (Sharifi-Tehrani, Verbič, \& Chung, 2013). This strategy diversifies risk and helps with short-term survival, but finds structural limits: dual pricing cannot entirely compensate for emergency situations that decrease tourism influx over a prolonged period. External economic support for loyal visitors has emerged as a method to increase revenue during crises (i.e., following 9/11; Bonham, Edmonds, \& Mak, 2006). One solution for museums could be to improve visitors' loyalty, increasing their likelihood of remaining involved with the museum after their visit and their willingness to contribute to museum initiatives from home. Positive experiences, and resultant loyalty, could incentivize 
participation in virtual tours or encourage online purchases from the museum, even when it cannot open (Thorson, Driscoll, Ekdale, Edgerly, Thompson, Schrock, Swarz., Vraga, \& Wells, 2013). Loyal consumers wishing to visit a museum again in the future may autonomously decide to participate in online crowdfunding campaigns to keep the museum afloat (Davies, 2015).

Using identification and loyalty derived from audience development strategies - i.e., ICT-driven digital experiences and SMMs - visitors' economic participation is incentivized. Economic support is influenced by many variables: age, gender, education, and engagement in cultural activities (Sharifi-Tehrani et al., 2013). Extant literature explores this, focusing on the relationship between loyalty and identification in tourism (Godovykh \& Tasci, 2020). When customers feel loyal, their willingness to pay more for the goods/services of the company is heightened (Bigné et al., 2008). Willingness to provide economic support increases when a consumer is more involved with a product or service. Loyal visitors make purchases from the museum even if prices increase or are higher than competitors. This has been referred to as a favorable "on the spot behavior" by museum advocators (Bigné et al., 2008).

Through the strategies of audience development and the creation of experiences, loyalty can be used as a predicting variable, increasing visitors' willingness to economically support the museum. Building on this, we propose:

H5: Visitors' loyalty to museums positively influences economic support intentions.

Our hypothesis relationships are shown in the conceptual model illustrated in Figure 1.

Insert Figure 1

\section{Methodology}




\section{Research instrument}

In 2019, we developed a self-reported questionnaire adopting existing measures previously validated by pertinent literature (see Appendix A for all items of the survey). The first section of the questionnaire consisted of 6 control variables related to respondents' socio-demographics (i.e., gender, age, education, most recent visited museum, and frequency of museum visits), while the second section was comprised of 43 items in six latent constructs, specifically: three first-order variables, such as visitor digital propensity (i.e., "Technology and digitalization give people more control over their daily lives"; Parasuraman, 2000); identification with the museum (i.e., "The museum has a great deal of personal meaning to me"; Meyer et al., 1993); and loyalty to the museum (i.e., "I would come back to the museum in the future"; Bigné et al., 2008). In addition, three second-order variables were considered: perceived museum SMMs (i.e., "Contents shown in the museum's social media seem interesting”; Kim \& Ko, 2012); digital experience (i.e., "Technologies and digitalization of the museum helped me find the visit interesting in a sensory way"; Brakus et al., 2009); and economic support (i.e., "I would visit again the museum even if the price increases"; Bigné et al., 2008).

The original questions were translated and adapted from English to Italian following back-translation techniques (Brislin, 1970). During the survey's planning and design, several measures were used to control for biases traditionally related to cross-sectional questionnaire techniques. Firstly, to avoid non-response bias (Rogelberg \& Stanton, 2007), the survey was pre-tested by five students enrolled in management and marketing courses at the University of Florence (Italy) and also by five academic experts in questionnaire methodology, tourism, and travelers'/visitors' behaviors. The aim was to ensure the survey was clearly and effectively designed, easy to complete, 
suitable in length, and with no grammar/lexical mistakes or ambiguous items. Because neither the students nor the academics suggested any significant modifications, no changes were made to the survey. Secondly, to decrease social desirability bias and related common method variance (Podsakoff, MacKenzie, Lee, \& Podsakoff, 2003), we stressed in the cover letter of the survey that participants' anonymity and researchers' confidentiality were ensured, as well as respondents' voluntary and non-compensated participation. Furthermore, following Podsakoff et al. (2003, p.887), we separated items pertaining to independent variables - such as digital propensity - from items pertaining to dependent variables - such as loyalty to the museum or economic support. Finally, we controlled for non-response bias by conducting wave analysis (Armstrong \& Overton, 1977). Early responses (March-April 2019) were compared with late responses (MayJune 2019) according to key variables, namely demographics variables and dependent variables - loyalty to the museum and economic support - and, as a result, no significant differences were shown in the $T$-tests, thus providing assurances regarding non-response bias.

\section{Data collection and analysis}

We decided to focus our sampling process on the region of Tuscany, which is one of the most important regions in Italy in terms of museums, art, and culture (ISTAT, 2020). Our sampling selection followed several eligibility criteria (i.e., visitors should have the following characteristics): 1) presence on social media platforms, such as social networking sites like Instagram, Facebook, Twitter, and LinkedIn; 2) follow online communities on museums, art, culture, and travels (both leisure, business, or bleisure); 3) visitors of museums at least once a year (screening question: Do you visit a museum once a year / twice a year / monthly / weekly?); 4) recently visited a Tuscan museum 
perceived as technologically/digitally advanced by the visitor (screening question:

Which is your most recently visited Tuscan museum that you consider

technologically/digitally advanced in terms of social media marketing

initiatives/activities and digital experience inside the museum?). We were able to collect 201 usable responses, which was deemed an appropriate sample size for conducting SEM analyses (Kline, 2015). We followed the instructions of Hair, Black, Babin, Anderson and Tatham (2006) in screening the data, individuating any issues with missing values, distribution of the data, and possible outliers with SPSS (v.26), which resulted in no data issues (Field, 2013). Consistently with contemporary tourism research (Chua, Al-Ansi, Lee, \& Han, 2020), the traditional two-step analysis of covariance-based structural equation modeling (CB-SEM) was performed using AMOS (v.26; Arbuckle, 2011): first, a measurement model assessed the psychometric properties of the hypothesized model constructs (statistical reliability and validity); next, a structural model evaluated the statistical influences among latent variables (direct and indirect regression weights).

\section{Results}

\section{Demographic information of the respondents}

Table 1 shows the respondents' demographics.

Insert Table 1

Most visitors were women (58.7\%), aged 19-29 (65.2\%), with a university degree (59.2\%). Most respondents visited museums twice a year (39.3\%) or monthly (29.9\%). The most recently visited Tuscan museums were the Uffizi Gallery $(30.3 \%)$ and the 
Museo dell'Opera del Duomo (11.4\%), both in Florence, followed by Centro Luigi Pecci (9.0\%), based in Prato.

\section{Psychometric properties of measures and correlation analysis}

We checked the reliability of each construct and the zero-order correlations, as presented in Table 2 .

Insert Table 2

All constructs showed satisfactory Cronbach alpha's $(\alpha)$ values, ranging from 0.735 (Affective of Digital Experience) to 0.924 (Loyalty), except for Trendiness (Perceived Museum SMMs) which showed a value of 0.609. Consistently with Loewenthal (2001) who suggested that $\alpha$ values above 0.6 are acceptable (see Hair, Sarstedt, Matthews, \& Ringle, 2016), we retained the Trendiness variable because of its importance in the following analyses. We deleted the BEHAVE3 item ("Digital technologies of "museum $X^{\prime \prime}$ were not action oriented") because it showed a low factor loading with the Behavioral construct (Digital Experience), significantly decreasing the overall statistical reliability $(\alpha)$ of the variable.

Concerning the correlation Pearson $r$ values, in line with pertinent literature, the firstorder variables related to the higher constructs Perceived Museum SMMs and Digital Experience were highly correlated (Brakus et al., 2009; Kim \& Ko, 2012). Visitors' Digital Propensity significantly correlated with Entertainment $(r=0.420)$ and Interaction $(r=0.430)$ of the Perceived Museum SMMs construct. Identification with the Museum was not significantly correlated with Digital Propensity $(p>0.10)$ but showed a high correlation with Intellectual $(r=0.409)$ of the Digital Experience 
construct and Loyalty $(r=0.464)$. Visitors' Willingness to Pay was strongly correlated with Loyalty $(r=0.667)$.

\section{Measurement model}

The first step of our CB-SEM analysis consisted of evaluating the validity of our hypothesized model through a confirmatory factor analysis (CFA) with AMOS (v.26). We deduced whether the factor loadings $(\lambda)$ - paths between second- and first-order variables - were significant and above the threshold of 0.3 (Hair et al., 2006; Kline, 2015). AMOS's maximum likelihood function was used to evaluate model parameters (Zollo, Faldetta, Pellegrini, \& Ciappei, 2017), such as the factor loadings and related significance, as shown in Table 3.

Insert Table 3

All sub-dimensions of Perceived Museum SMMs were significantly and strongly $(\lambda>$ 0.80) associated with the higher construct. All sub-dimensions of Digital Experience were highly $(\lambda>0.70)$ associated with their second-order construct. Concerning Economic Support, the sub-dimension Willingness to Pay More showed the highest factor loading $(\lambda=0.91)$, while On the Spot Behavior had a lower, yet still acceptable, factor loading $(\gamma=0.49)$.

We assessed the goodness-of-fit measures of the hypothesized six-factor model (Bagozzi \& Yi, 1988). Values of absolute fit indexes were satisfactory, namely: 1) the relative Chi-square test suggested an acceptable model fit equal to 2.408 - less than 3 , as required; 2) the goodness-of-fit index (GFI) was equal to 0.902 - above 0.9 , as required; 3) the root mean square error of approximation (RMSEA) was equal to 0.084 - lower than 0.10, as required (see Bagozzi \& Yi, 1988). We then calculated relative fit 
indexes, which were all higher than the 0.9 required threshold: the comparative fit index $(\mathrm{CFI}=0.943)$, the incremental fit index $(\mathrm{IFI}=0.943)$, the normed fit index $(\mathrm{NFI}=$ 0.907), and the Tucker-Lewis index $(\mathrm{TLI}=0.927)$. All goodness-of-fit measures were satisfactory. We assessed the indicators' internal consistency through the composite reliability $(\mathrm{CR})$ measure for all constructs. All were higher than the threshold of 0.7 (Bagozzi \& Yi, 1988; Hair et al., 2016). The convergent validity of each construct was computed through the average variance extracted (AVE), with values above the required threshold of 0.5 . Finally, the discriminant validity of the constructs was measured comparing the square root of AVE values with the zero-order correlation values shown in Table 2. The latter were lower than the $\sqrt{A V E}$ values, as required. The measurement model analyses suggested a good fit for each construct and the whole model.

The final assessment checked for the presence of common method bias (CMB). We followed the guidelines of Podsakoff, MacKenzie and Podsakoff (2012): a) all scales of the questionnaire were pre-tested to remove ambiguous items; b) we conducted the Harman's one-factor test, showing that the single factor accounted for $31.50 \%$ of the total variance, demonstrating that no single factor accounted for the majority $(>50 \%)$ of the variance; c) a CFA was performed to compare our model with the "one-factor model", in which all items load onto a common factor (Podsakoff et al., 2003; 2012). There was a significant change in Chi-square and a superior data fit in respect of the "one-factor model". CMB was thus less likely to be a critical issue.

\section{Structural model}

The second step of our CB-SEM analysis consisted of evaluating regression weights paths or statistical influences among latent variables - to empirically test the hypothesized relationships (see Figure 2). 
Insert Figure 2

Visitors' Digital Propensity positively influenced Digital Experience $(\beta=+0.202$; $p<0.01$ ), thus supporting Hla. Digital Propensity strongly influenced Perceived Museum SMMs $(\beta=+0.483 ; p<0.01)$, thus empirically supporting $H 1 b$. $H 1$ was confirmed, showing visitors' attitudes towards digitalization were strong antecedents and predictors of visitors' perceptions of the museum SMMs and their digital and technological experience inside the museum. Both Perceived Museum SMMs $(\beta=$ $+0.296 ; p<0.01)$ and Digital Experience $(\beta=+0.249 ; p<0.01)$ positively impacted Loyalty, thus confirming $H 2 a$ and $H 2 b$. This showed perceptions of social media activities and digital experience on-site have a parallel effect on loyalty, representing two strategic levers for museum managers/marketers. The mediation analysis ( $H 3$ and H4) followed Baron and Kenny's (1986) four-step procedure: 1) the first condition was already reported as Digital Experience (the " $\mathrm{X}$ " variable/input variable) significantly impacted Loyalty (the "Y" variable/output variable); 2) the second step implies that the " $X$ " variable significantly impacts the mediating variable, i.e., Identification with the Museum (the "M" variable). Because Digital Experience positively impacted Identification with the Museum $(\beta=+0.402 ; p<0.01)$, this condition was supported and $H 3 a$ was confirmed; 3 ) the third step implies that the "M" variable significantly impacts the "Y" variable; because Identification with the Museum positively impacted Loyalty $(\beta=+0.398 ; p<0.01)$, this was empirically supported, confirming $H 3 b ; 4)$ the fourth step shows the original relationship between " $\mathrm{X}$ " and " $\mathrm{Y}$ " $(\beta=+0.249 ; p<0.01)$ must be lessened or become non-significant because of the "M" variable, resulting in partial or full mediating effects (see Rialti, Zollo, Ferraris, \& Alon, 2019). Because the original effect was lessened $(\beta=+0.159 ; p<0.01)$, we could consider Identification with the 
Museum a partially significant mediating variable on the relationship between Digital Experience and Loyalty. $H 4$ thus found empirical support. This mediating effect suggests visitors' emotional attachment and identification with the museum emerges as a significant underlying mechanism explaining how loyalty to a museum arises through digital and technological experiences. Our model has a good explanatory power for the Loyalty variable. Through the multiple square correlation index $\left(R^{2}\right)$ in Figure 2, we were able to explain $30 \%$ of the variance in loyalty thanks to the combined effect of all considered variables - namely, digital propensity, museum SMMs, digital experience, and identification. Loyalty was a significant and strong predictor of Economic Support $(\beta=+0.735 ; p<0.01)$, confirming $H 5$. This statistical influence provided the strongest regression weight of the model, highlighting the importance of loyalty in predicting and impacting willingness to economically support the museum. We also acknowledged the power of the whole model in explaining the variance of the Economic Support variable: as shown in Figure 2, 54\% of the variance was explained by antecedent variables, thus demonstrating their importance in predicting mechanisms fostering the economic support of a museum.

\section{Discussion}

Building on experiential marketing (Pine \& Gilmore, 1998; Brakus et al., 2009) and the TAM2 theory (Venkatesh \& Davis, 2000), this research sought to investigate whether or not new technologies, digitalization, and ICT might represent strategic levers for museums managers/marketers to use to improve loyalty and increase museums' economic support. We explored the simultaneous role of museums' social media activities and initiatives - providing online entertainment, interaction, trendiness, and customization (Kim \& Ko, 2012) - and visitors' overall digital experience (in terms of 
sensory, affective, behavioral, and intellectual experiences) regarding artistic exhibitions (Brakus et al., 2009). Digital experiences and the presence of museums on online environments/platforms (SMMs) were found to be significant predictors of loyalty which, in turn, impacted visitors' willingness to pay more and buy products/souvenir from the museum's store - referred to as economic support (Bigné et $a l .$, 2008). Visitors' identification with the museum (Meyer et al., 1993) was a significant explanatory (i.e., "mediating”) underlying mechanism in the relationship between their digital experience in the museum and loyalty. All of these relationships were based on the main antecedent variable of the framework, which interprets digital propensity as visitors' positive attitudes towards technology and digitalization (Parasuraman, 2000; Parasuraman \& Grewal, 2000). Tech-savvy tourists will enjoy and appreciate the overall digital experience, thus identifying themselves with and feeling part of the museum, becoming loyal, and willingly providing economic support. These findings are in line with recent marketing research which demonstrates the need for brand managers/marketers to invest in new technologies, such as social media and ecommerce, to attract and retain customers - specifically millennials and the tech-savvy to generally enhance their consumer-based brand equity (i.e., CBBE; see Faraoni, Rialti, Zollo, \& Pellicelli, 2019; Rialti, Zollo, Pellegrini, \& Ciappei, 2017; Zollo et al., 2020). Rialti et al. (2018) highlight the need for brand strategists to involve members of social media brand communities to create value co-creation experiences between brands and customers. In this context, place branding scholars have found that photos and posts on social networking sites, like Instagram and Telegram, significantly correlate with tourists' place association, branding, image, reputation, and, most importantly, tourism experience (Ebrahimi et al., 2020). Wong, Lai and Tao (2020) demonstrated the positive influence of sharing memorable tourist experiences on social media on tourists' intent to 
visit. Museum marketers thus need to exploit these new digital channels of communication to engage, involve, and attract new visitors, especially young and techsavvy tourists who participate more in these online communities (Rialti et al., 2017). Furthermore, museums should provide a coherent "digital experience" to tech-savvy visitors, incorporating ICT inside the museum and as part of an artistic exhibition. According to Kwok and Koh's (2020) investigation of extended reality in tourism, virtual and augmented reality, such as 3D videos or 360-degree tours, might provide a sustainable competitive advantage to destination marketers, especially when coping with the COVID-19 pandemic. Consistent with our results, new technologies and digitalization are appreciated by tech-savvy visitors, who might become advocates of the museum themselves and endorse it through e-WOM and online communities (Anton, Camarero, \& Garrido, 2018; Zollo, Yoon, Rialti, \& Ciappei 2018). This creates a positive digital touchpoint along visitors' consumer journeys, particularly in the postexperience phase, wherein tourists post reviews, comments, and photos of the museum online (Ebrahimi et al., 2020; Wong et al., 2020).

\section{Limitations and future research}

The first limitation of this research is the cross-sectional nature of the adopted methodology. We suggest future researchers test our hypothesized relationships through a longitudinal study or using an experimental design, wherein visitors' attitudes and behavior can be captured directly during their museum visit. Our study focused on a single Italian region (Tuscany) and our results are thus not generalizable to different destination areas. However, this allows future researchers to test our hypothesized model in culturally different areas and more individualistic (USA) or collectivistic (Asia) locations. Finally, our proposed framework might be expanded by future tourism 
scholars with more variables able to better explain the underlying mechanisms between the constructs. For example, visitor satisfaction and commitment might be interpreted as significant mediating variables of the relationships between digital experience, loyalty, and economic support. Moreover, several moderators, such as demographic variables, might be included in the model to investigate whether or not results vary across generations (generation Z, millennials, baby boomers, etc.) or cultures (individualistic, collectivistic).

\section{References}

Anton, C., Camarero, C., \& Garrido, M.J. (2018). Exploring the experience value of museum visitors as a co-creation process. Current Issues in Tourism, 21(12), 1406-1425.

Arbuckle, J.L. (2011). Amos 20 User's Guide. SPSS, Chicago, IL.

Armstrong, J.S., \& Overton, T.S. (1977). Estimating nonresponse bias in mail surveys. Journal of Marketing Research, 14(3), 396-402.

Ayala, I., Cuenca-Amigo, M., \& Cuenca, J. (2019). Examining the state of the art of audience development in museums and heritage organisations: a systematic siterature review. Museum Management and Curatorship, 35(3), 306-327.

Bagozzi, R.P. (1992). The self-regulation of attitudes, intentions, and behavior. Social Psychology Quarterly, 55(2), 178-204.

Bagozzi, R.P. \& Yi, Y. (1988). On the evaluation of structural equation models. Journal of the Academy of Marketing Science, 16(1), 74-94.

Baron, R.M., \& Kenny, D.A. (1986). The moderator-mediator variable distinction in social psychological research: Conceptual, strategic, and statistical considerations. Journal of Personality and Social Psychology, 51(6), 1173. 
Belanche, D., Flavián, C., \& Pérez-Rueda, A. (2017). Understanding interactive online advertising: Congruence and product involvement in highly and lowly arousing, skippable video ads. Journal of Interactive Marketing, 37, 75-88.

Bigné, J.E., Mattila, A.S., \& Andreu, L. (2008). The impact of experiential consumption cognitions and emotions on behavioral intentions. Journal of Services Marketing, $22(4), 303-315$.

Bonacini, E. (2016). Il Museo Salinas: un case study di social museum... a porte chiuse/The Salinas Museum: a case study of social museums... behind closed doors. Il capitale culturale. Studies on the Value of Cultural Heritage, 13, 225266.

Bonham, C., Edmonds, C., \& Mak, J. (2006). The impact of 9/11 and other terrible global events on tourism in the United States and Hawaii. Journal of Travel Research, 45(1), 99-110.

Brakus, J.J., Schmitt, B.H., \& Zarantonello, L. (2009). Brand experience: what is it? How is it measured? Does it affect loyalty?. Journal of Marketing, 73(3), 52-68.

Brislin, R. W. (1970). Back-translation for cross-cultural research. Journal of CrossCultural Psychology, 1(3), 185-216.

Cerquetti, M. (2016). More is better! Current issues and challenges for museum audience development: a literature review. Current Issues and Challenges for Museum Audience Development: A Literature Review. Journal of Cultural Management and Policy, 6(1), 30-43.

Cheng, J.M.S., Blankson, C., Wang, E.S.T., \& Chen, L.S.L. (2009). Consumer attitudes and interactive digital advertising. International Journal of Advertising, 28(3), $501-525$ 
Chua, B.L., Al-Ansi, A., Lee, M.J., \& Han, H. (2020). Impact of health risk perception on avoidance of international travel in the wake of a pandemic. Current Issues in Tourism, 1-18. DOI: https://doi.org/10.1080/13683500.2020.1829570

Cillo, V., Rialti, R., Del Giudice, M., \& Usai, A. (2019). Niche tourism destinations' online reputation management and competitiveness in big data era: Evidence from three Italian cases. Current Issues in Tourism, DOI: https://doi.org/10.1080/13683500.2019.1608918

Cohen, M.M. (2016). “Always on and always on them": Portable radios and the creation of the mobile media experience. Mobile Media and Communication, 4(3), 371384.

Csikszentmihalyi, M. (1990). Flow: The psychology of optimal experience. New York: Harper \& Row.

David, C. (1999). Elitism in the stories of US art museums: The power of a master narrative. Journal of Business and Technical Communication, 13(3), 318-335.

Davies, R. (2015). Three provocations for civic crowdfunding. Information, Communication \& Society, 18(3), 342-355.

Dirsehan, T. \& Yalçin, A.M. (2011). Comparison between holistic museum visitors and utilitarian museum visitors. International Journal of Marketing Studies, 3(4), 7888.

Domínguez-Quintero, A.M., González-Rodríguez, M.R., \& Paddison, B. (2020). The mediating role of experience quality on authenticity and satisfaction in the context of cultural-heritage tourism. Current Issues in Tourism, 23(2), 248-260.

Easson, H. \& Leask, A. (2019). After-hours events at the National Museum of Scotland: a product for attracting, engaging and retaining new museum audiences?. Current Issues in Tourism, 23(11), 1343-1356. 
Ebrahimi, P., Hajmohammadi, A., \& Khajeheian, D. (2020). Place branding and moderating role of social media. Current Issues in Tourism, 23(14), 1723-1731.

Faraoni, M., Rialti, R., Zollo, L., \& Pellicelli, A.C. (2019). Exploring e-loyalty antecedents in B2C e-commerce. British Food Journal, 121(2), 574-589.

Field, A. (2013). Discovering Statistics Using IBM SPSS Statistics. Sage, Thousand Oaks, CA.

Fissi, S., Gori, E., \& Contri, M. (2018). Il peso del "privato" nei musei statali italiani: verso strumenti e figure innovative?. Economia Aziendale Online, 9(3), 261-289.

Fissi, S., Gori, E., Romolini, A., \& Contri, M. (2019). Stakeholder engagement: verso un utilizzo dei Social Media nei musei italiani?. Management Control, (1), 145160.

Fu, F. Q., Bolander, W., \& Jones, E. (2009). Managing the drivers of organizational commitment and salesperson effort: An application of Meyer and Allen's threecomponent model. Journal of Marketing Theory and Practice, 17(4), 335-350.

Gangadharbatla, H. (2008). Facebook me: Collective self-esteem, need to belong, and internet self-efficacy as predictors of the iGeneration's attitudes toward social networking sites. Journal of Interactive Advertising, 8(2), 5-15.

Godovykh, M. \& Tasci, A.D. (2020). The influence of post-visit emotions on destination loyalty. Tourism Review. DOI: https://doi.org/10.1108/TR-01-20200025

Hair, J.F., Sarstedt, M., Matthews, L.M., \& Ringle, C.M. (2016). Identifying and treating unobserved heterogeneity with FIMIX-PLS: part I-method. European Business Review, 28(1), 63-76.

Hair, J.F., Black, W.C., Babin, B.J., Anderson, R.E., \& Tatham, R.L. (2006). Multivariate Data Analysis, Vol. 6. Pearson Prentice Hall, New York, NJ. 
Harrison, P. \& Shaw, R. (2004). Consumer satisfaction and post-purchase intentions: An exploratory study of museum visitors. International Journal of Arts Management, 6(2), 23-32.

Hooper-Greenhill, E. (2000). Changing values in the art museum: Rethinking communication and learning. International Journal of Heritage Studies, 6(1), 931.

ISTAT (2020). Comunicato Stampa. I Musei Statali al Tempo del COVID-19 (21 May 2020). Available online at: https://www.istat.it/it/archivio/243286

Karaman, S., Bagdanov, A.D., Landucci, L., D’Amico, G., Ferracani, A., Pezzatini, D., \& Del Bimbo, A. (2016). Personalized multimedia content delivery on an interactive table by passive observation of museum visitors. Multimedia Tools and Applications, 75(7), 3787-3811.

Kaplan, A.M. \& Haenlein, M. (2010). Users of the world, unite! The challenges and opportunities of Social Media. Business Horizons, 53(1), 59-68.

Kawashima, N. (1998). Knowing the public: A review of museum marketing literature and research. Museum Management and Curatorship, 17(1), 21-39.

Kelly, L. (2004). Evaluation, research and communities of practice: Program evaluation in museums. Archival Science, 4(1-2), 45-69.

Kesner, L. (2006). The role of cognitive competence in the art museum experience. Museum Management and Curatorship, 21(1), 4-19.

Kim, A.J. \& Ko, E. (2012). Do social media marketing activities enhance customer equity? An empirical study of luxury fashion brand. Journal of Business Research, 65(10), 1480-1486.

Kline, R.B. (2015). Principles and practice of structural equation modeling. The Guilford Press, New York, NJ. 
Kwok, A.O. \& Koh, S.G. (2020). COVID-19 and extended reality (XR). Current Issues in Tourism. DOI: 10.1080/13683500.2020.1798896.

Laroche, M., Habibi, M.R., \& Richard, M.O. (2013). To be or not to be in social media: How brand loyalty is affected by social media?. International Journal of Information Management, 33(1), 76-82.

Li, Y.C., Liew, A.W.C., \& Su, W.P. (2012). The digital museum: Challenges and solution. In 2012 8th International Conference on Information Science and Digital Content Technology (ICIDT2012) (Vol. 3, 646-649).

Liu, Y., Hultman, M., Eisingerich, A.B., \& Wei, X. (2020). How does brand loyalty interact with tourism destination? Exploring the effect of brand loyalty on place attachment. Annals of Tourism Research, 81, DOI: https://doi.org/10.1016/j.annals.2020.102879

Loewenthal, K.M. (2001). An Introduction to Psychological Tests and Scales. Taylor and Francis, Philadelphia, PA.

McLean, F. (1994). Services marketing: the case of museums. Service Industries Journal, 14(2), 190-203.

Meyer, J. P., Allen, N. J., \& Smith, C. A. (1993). Commitment to organizations and occupations: Extension and test of a three-component conceptualization. Journal of Applied Psychology, 78(4), 538-551.

Neuhofer, B., Buhalis, D., \& Ladkin, A. (2014). A typology of technology-enhanced tourism experiences. International Journal of Tourism Research, 16(4), 340-350.

O’Connor, M.C., Nelson, K.C., Pradhananga, A., \& Earnest, M.E. (2020). Exploring How Awareness-making Elicits Meaning-making in Museum Visitors: A Mixedmethods Study. Journal of Museum Education, 45(2), 187-199. 
Padilla-Melendez, A. \& del Águila-Obra, A.R. (2013). Web and social media usage by museums: Online value creation. International Journal of Information Management, 33(5), 892-898.

Pallud, J., \& Straub, D.W. (2014). Effective website design for experience-influenced environments: The case of high culture museums. Information \& Management, 51(3), 359-373.

Parasuraman, A. (2000). Technology Readiness Index (TRI) a multiple-item scale to measure readiness to embrace new technologies. Journal of Service Research, 2(4), 307-320.

Parasuraman, A. \& Grewal, D. (2000). The impact of technology on the quality-valueloyalty chain: a research agenda. Journal of the Academy of Marketing Science, 28(1), 168-174.

Payne, A.F., Storbacka, K., \& Frow, P. (2008). Managing the co-creation of value. Journal of the Academy of Marketing Science, 36(1), 83-96.

Perez-Sanagustín, M., Parra, D., Verdugo, R., García-Galleguillos, G., \& Nussbaum, M. (2016). Using QR codes to increase user engagement in museum-like spaces. Computers in Human Behavior, 60, 73-85.

Pesce, D., Neirotti, P., \& Paolucci, E. (2019). When culture meets digital platforms: value creation and stakeholders' alignment in big data use. Current Issues in Tourism, 22(15), 1883-1903.

Petrick, J.F. \& Backman, S.J. (2002). An examination of the construct of perceived value for the prediction of golf travelers' intentions to revisit. Journal of Travel Research, 41(1), 38-45.

Pine, B.J. \& Gilmore, J.H. (1998). Welcome to the experience economy. Harvard Business Review, 76, 97-105. 
Podsakoff, P.M., MacKenzie, S.B., \& Podsakoff, N.P. (2012). Sources of method bias in social science research and recommendations on how to control it. Annual Review of Psychology, 63, 539-569.

Podsakoff, P.M., MacKenzie, S.B., Lee, J.Y., \& Podsakoff, N.P. (2003). Common method biases in behavioral research: a critical review of the literature and recommended remedies. Journal of Applied Psychology, 88(5), 879-903.

Pujol-Tost, L. (2011). Integrating ICT in exhibitions. Museum Management and Curatorship, 26(1), 63-79.

Rialti, R., Zollo, L., Boccardi, A., \& Marzi, G. (2016). The impact of technologies on visitors' experience personalization: a case study. Micro \& Macro Marketing, (2), 251-280.

Rialti, R., Zollo, L., Pellegrini, M.M., \& Ciappei, C. (2017). Exploring the antecedents of brand loyalty and electronic word of mouth in social-media-based brand communities: do gender differences matter?. Journal of Global Marketing, 30(3), 147-160.

Rialti, R., Caliandro, A., Zollo, L., \& Ciappei, C. (2018). Co-creation experiences in social media brand communities. Spanish Journal of Marketing-ESIC, 22(2), 122141.

Rialti, R., Zollo, L., Ferraris, A., \& Alon, I. (2019). Big data analytics capabilities and performance: Evidence from a moderated multi-mediation model. Technological Forecasting and Social Change, 149. DOI: 10.1016/j.techfore.2019.119781.

Rogelberg, S.G., \& Stanton, J.M. (2007). Introduction: Understanding and dealing with organizational survey nonresponse. Organizational Research Methods, 10(2), 195-209. 
Romolini, A., Fissi, S., \& Gori, E. (2020). Visitors engagement and social media in museums: evidence from Italy. International Journal of Digital Culture and Electronic Tourism, 3(1), 36-53.

Samaroudi, M., Echavarria, K.R., \& Perry, L. (2020). Heritage in lockdown: digital provision of memory institutions in the UK and US of America during the COVID-19 pandemic. Museum Management and Curatorship, 35(4), 337-361.

San Martin, H., Collado, J., \& Rodriguez del Bosque, I. (2013). An exploration of the effects of past experience and tourist involvement on destination loyalty formation. Current Issues in Tourism, 16(4), 327-342.

Sashi, C.M. (2012). Customer engagement, buyer-seller relationships, and social media. Management Decision, 50(2), 253-272.

Sawyer, S., Griffiths, M., Light, B., Lincoln, S., \& Kidd, J. (2011). Enacting engagement online: framing social media use for the museum. Information Technology \& People, 24(1), 64-77.

Sharifi-Tehrani, M., Verbič, M., \& Chung, J.Y. (2013). An analysis of adopting dual pricing for museums: The case of the national museum of Iran. Annals of Tourism Research, 43, 58-80.

Statista (2018). Reasons for collecting art among millennial art collectors in the United States as of February 2018. Available online at: https://www.statista.com/statistics/893935/reasons-for-collecting-art-amongmillennial-art-collectors-united-states/

Statista (2019). Most Visited Art Museums Worldwide in 2019. Available online at: https://www.statista.com/statistics/246293/art-museums-by-total-attendanceworldwide/ 
Suhartanto, D., Brien, A., Primiana, I., Wibisono, N., \& Triyuni, N.N. (2019). Tourist loyalty in creative tourism: the role of experience quality, value, satisfaction, and motivation. Current Issues in Tourism, 23(7), 867-879.

Taheri, B., Jafari, A., \& O'Gorman, K. (2014). Keeping your audience: Presenting a visitor engagement scale. Tourism Management, 42, 321-329.

tom Dieck, M.C., Jung, T.H., \& tom Dieck, D. (2018). Enhancing art gallery visitors' learning experience using wearable augmented reality: generic learning outcomes perspective. Current Issues in Tourism, 21(17), 2014-2034.

Thorson, K., Driscoll, K., Ekdale, B., Edgerly, S., Thompson, L.G., Schrock, A., Swarz, L., Vraga, E.K., \& Wells, C. (2013). YouTube, Twitter and the Occupy movement: Connecting content and circulation practices. Information, Communication \& Society, 16(3), 421-451.

Trunfio, M., Campana, S., \& Magnelli, A. (2020). Measuring the impact of functional and experiential mixed reality elements on a museum visit. Current Issues in Tourism, 23(16), 1990-2008.

Tung, V.W.S. \& Ritchie, J.B. (2011). Exploring the essence of memorable tourism experiences. Annals of Tourism Research, 38(4), 1367-1386.

Vandenberghe, C., Bentein, K., \& Panaccio, A. (2017). Affective commitment to organizations and supervisors and turnover: A role theory perspective. Journal of Management, 43(7), 2090-2117.

Venkatesh, V. \& Davis, F.D. (2000). A theoretical extension of the technology acceptance model: Four longitudinal field studies. Management Science, 46(2), 186-204. 
Wong, J.W.C., Lai, I.K.W., \& Tao, Z. (2020). Sharing memorable tourism experiences on mobile social media and how it influences further travel decisions. Current Issues in Tourism, 23(14), 1773-1787.

Yu, M., Li, Z., Yu, Z., He, J., \& Zhou, J. (2020). Communication related health crisis on social media: a case of COVID-19 outbreak. Current Issues in Tourism. DOI: $10.1080 / 13683500.2020 .1752632$.

Zarantonello, L. \& Schmitt, B.H. (2013). The impact of event marketing on brand equity: The mediating roles of brand experience and brand attitude. International Journal of Advertising, 32(2), 255-280.

Zollo, L., Faldetta, G., Pellegrini, M. M., \& Ciappei, C. (2017). Reciprocity and giftgiving logic in NPOs. Journal of Managerial Psychology, 32(7), 513-526.

Zollo, L., Yoon, S., Rialti, R., \& Ciappei, C. (2018). Ethical consumption and consumers' decision making: the role of moral intuition. Management Decision, $56(3), 692-710$.

Zollo, L., Filieri, R., Rialti, R., \& Yoon, S. (2020). Unpacking the relationship between social media marketing and brand equity: The mediating role of consumers' benefits and experience. Journal of Business Research, 117, 256-267. 